\title{
Analysis Of Using Islamic Bank Social Media And Website In The E-Marketing Concept Using Attention, Interest, Search, Action, Share (AISAS) Methods
}

\author{
Silmi Safira ${ }^{1}$, Iqbal Fadli Muhammad ${ }^{2}$, Muhammad Doddy ${ }^{3}$ \\ ${ }^{I}$ SEBI: silmisafira7@gmail.com \\ ${ }^{2}$ SEBI Lecturer. Email:qbalfm37@gmail.com \\ ${ }^{3}$ SEBI Lecturer \& Doctoral Candidate AeU Malaysia Email : doddy.abe@gmail.com
}

\begin{abstract}
This study aims to analyze the extent to which Islamic banks, especially sharia commercial banks, have used websites and social media in the concept of emarketing. The scope of this research is 13 Islamic commercial banks. The method used is the AISAS method (Attention, Interest, Seacrh, Action, Share). The result is that from the 13 Islamic banks, the top 5 banks in utilizing websites and social media for $e$ marketing are: Bank Syariah Mandiri, Bank BNI Syariah, Bank Muamalat, BRI Syariah Bank, and BJB Syariah Bank. implication of this study is that Islamic banking is better at maximizing the approach to the community by utilizing digital media to get the attention of customers or prospective customers. Because in modern times social media is something that is so important for people's lives.
\end{abstract}

Keywords: E-Marketing, AISAS, Islamic Commercial Bank, Website, Social Media

\section{INTRODUCTION}

Technology evolves following human development. Today's technology is increasingly sophisticated and causes major changes to the world. Technology is a tool that can help most human needs. Technology can be used by humans to make it easier to do whatever tasks and jobs. This important role of technology is what brings human civilization into the digital era.

As is the case in financial institutions, especially banks, technological advances make a significant contribution to the ease of transactions. With the use of technology, it makes it easy to serve customers both in transactions and other bank operational activities, so that banking activities become more effective and efficient (Mardiah, 2017). 
70 | Silmi Safira, Iqbal Fadli Muhammad, Muhammad Doddy: The Concept of Branding in Islamic Business Ethics Perspetive Analysis of Using Islamic Bank Social Media and Website in The e-Marketing Concept Using Attention, Interest, Search, Action, Share (AISAS) Methods

\section{Graph 1 Number of Islamic Banking Customers in 2018}

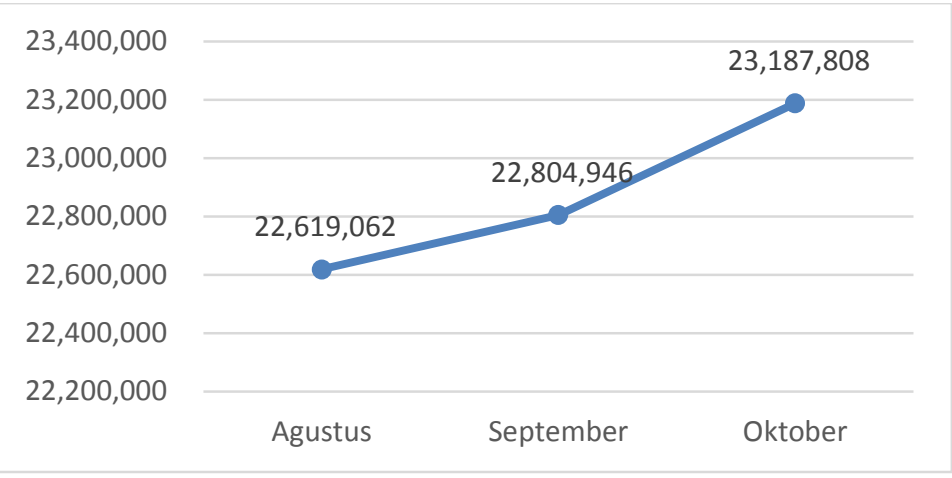

Source: Processed from Islamic Banking Statistics, OJK

Based on Graph 1, the number of Islamic bank customers continues to increase, where in August the number of customers was 22,619,062 while in September the number of customers was $22,804,946$ and in October the number of customers reached 23,187,808.

To achieve competitive advantage, Islamic banking can utilize the rapidly developing technology nowadays to promote or introduce Islamic banking products and services using the Internet.

\section{Graph 1.2 Increased Internet Users in Indonesia}

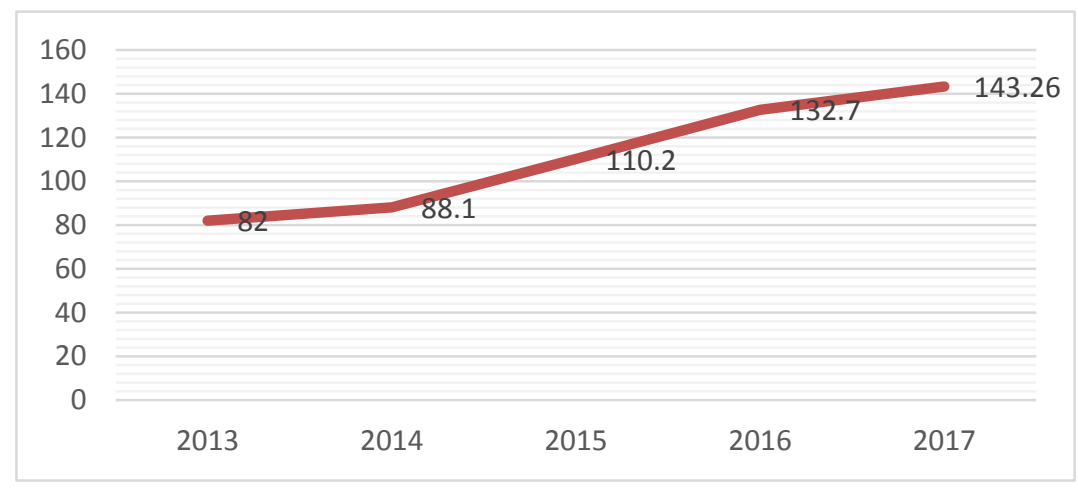

Source: Processed from the Association of Indonesian Internet Service Providers (APJII)

According to graph 1.2, the number of internet users continues to increase from year to year. In 2016 the number of internet users in Indonesia penetrated 132.7 million and in 2017 it increased to 143.26 million users.

Based on the Islamic banking statistics in October 2018 the cost of promoting Islamic banking is Rp. 15,633,000,000. By utilizing the internet as a 
Jurnal Ekonomi dan Perbankan Syariah

Vol. 7. No.1, April 2019: 60-78, ISSN (cet): 2355-1755 | ISSN (online): 2579-

6437

| 71

promotional tool, it is hoped that Islamic banks can reduce the promotional costs incurred.

According to Wandanaya (2012), companies can apply a marketing method using cheaper electronic media, namely the internet, so companies can reduce marketing costs and can increase sales volume.

\section{Graph 3: Internet Services that Are Accessed}

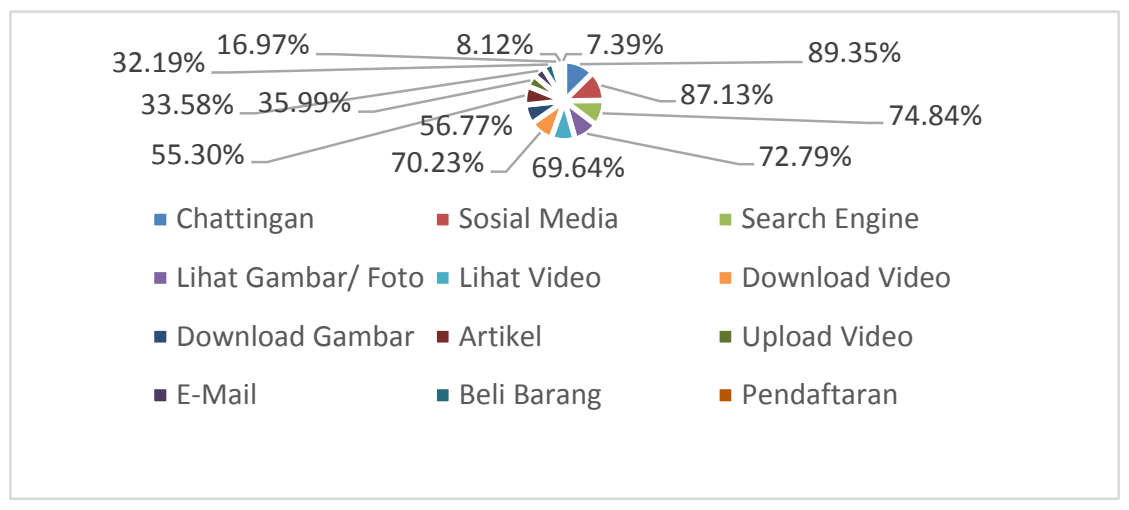

Source: Processed from the Association of Indonesian Internet Service Providers (APJII)

According to the Association of Indonesian Internet Service Providers (APJII), Social media is ranked second in the internet service that is accessed by the public at $87.13 \%$. Whereas for banks, it is located at the last position of services accessed, which is $7.39 \%$. With that, we can make social media a place to promote our bank's products and services to the community.

According to Rofiq, Arifin, \& Wilopo (2012), Every company or marketer has its own concepts in marketing a product. In the marketing communication sciences, the AIDA concept is known as a reference in making communication campaign programs, and often the AIDA concept becomes the initial foundation in making marketing programs.

This model eventually developed until other forms emerged, including AIDMA (Attention, Interest, Desire, Memory, Action), which was more concentrated on the model of consumption behavior in the world of broadcasting. In the end, there is now AISAS (Attention, Interest, Search, Action, Share), which is a model of consumption behavior initiated by Dentsu in 2004. This model emerged after the rapid development of the internet in the global world. AISAS is more concentrated on how the consumption of an item and service is done, one of which is the large role of the internet. (Wirawan \& Hapsari, 2016)

By using the AISAS model (Attention, Interest, Seacrh, Action, Share), we hope that we can analyze whether the Islamic bank has implemented the 
72 | Silmi Safira, Iqbal Fadli Muhammad, Muhammad Doddy: The Concept of Branding in Islamic Business Ethics Perspetive Analysis of Using Islamic Bank Social Media and Website in The e-Marketing Concept Using Attention, Interest, Search, Action, Share (AISAS) Methods internet as a promotional tool? And whether using internet media as a promotional tool can encourage customers to make transactions? and to what extent do customers use the internet as a reference tool for financing in an Islamic bank?

Armed with this background, the author conducted more research into the use of Islamic Commercial Bank websites and social media on the concept of emarketing.

\section{LITERATURE REVIEW}

\section{E-MARKETING AND SOCIAL MEDIA}

\section{E-Marketing}

e-Marketing is the process of marketing products and services to customers using web media, promotions, advertisements, transactions and payments that can be done through web pages so as to facilitate access to information anywhere (Priansa, 2017). The purpose of e-Marketing according to Priansa (2017) is:

1) Facilitate the promotion of products and services interactively and realtime through direct communication channels via the internet.

2) Creating new distribution channels that can reach more customers in almost all parts of the world.

3) More responsive and satisfying customer service, because customers can get more detailed information and quick response online.

4) Facilitating mass customization of products and services, as has been applied to a number of products so that prospective customers can design their own variety of products according to their respective preferences.

5) Facilitate one-to-one or direct advertising applications that are more effective than mass advertising.

6) Build the right brand image and company image.

\section{Social Media and Website}

Abdullah (2018), websites can be interpreted as a collection of pages that contain digital data information in the form of text, images, animation, sound and video or a combination of everything provided through an internet connection, so that it can be accessed and seen by everyone around the world.

Social Media is a media that designs to facilitate interactive or two-way social interactions. Social media based on the internet changes the pattern of information dissemination from the previous one to many audiences. Social media is a platform on the internet that allows users to interact with each other. Which includes social media including: blogs (WordPress, Medium, Blogger, 
Jurnal Ekonomi dan Perbankan Syariah

Vol. 7. No.1, April 2019: 68-78, ISSN (cet): 2355-1755 | ISSN (online): 2579-

6437

\section{3}

etc.), forums (Kaskus, DetikForum, Fimela, etc.), video platforms (Youtube, Vimeo, IGTV, etc.), social networking (Facebook, Instagram, Twitter, etc.) (Muljono, 2018).

\section{FanPage}

Facebook allows every business to create a Facebook page on the network. Or commonly referred to as FanPage. This is the page where you post all the content that fans and followers of your brand may find interesting. If people want to stay in touch with your business through Facebook, they do it through your page. They can send you messages and share their own content on your page if you allow it (Hope, 2016).

\section{Instagram}

Instagram or other terms with the word photo sharing is mass media that is very popular nowadays because it has added value in terms of filters or effects. Instagram can be said to resemble Twitter, where we can follow other people and other people can also follow us back (Interprise, 2013).

\section{Twitter}

Ardha (2014) Said, Twitter is a free internet-based microblogging service, where users can send short, 140 character messages to each other. Its use is based on a quick exchange of thoughts and information among friends, acquaintances, and all users of the Twitter platform. Twitter messages are most often called "tweets". This Tweet forms a message stream that is followed in chronological order from a computer screen or other screen, such as one from a cellphone. A kind of keyword called "hashtag" can be added to a tweet to connect the current message with several other messages, making it easier to follow the message.

\section{AISAS METHOD}

AISAS (Attention, Interest, Seacrh, Action, Share) is the process of a consumer who pays attention to products, services, or advertisements (Attention) and creates interest (Interest) so that the desire arises to gather information (Search) about the item. Searches can be made on the Internet on blogs written by other people, product comparison sites, and company official web pages, or by talking to family or friends who have actually used the appropriate product or service. Consumers then make an overall assessment based on the information gathered and the information presented by the company, taking into account the comments and opinions of people who have bought and used the product or service. If successful, then it becomes a decision to make a purchase (Action). After purchase, consumers become information carriers (word of mouth), by talking to other people or by sending comments and shows on the internet (Sharing) (Sugiyama \& Andree, 2011). 
74 | Silmi Safira, Iqbal Fadli Muhammad, Muhammad Doddy: The Concept of Branding in Islamic Business Ethics Perspetive Analysis of Using Islamic Bank Social Media and Website in The e-Marketing Concept Using Attention, Interest, Search, Action, Share (AISAS) Methods

Sugiyama \& Andree (2011) also say, that the AISAS model was initially created to accommodate the emergence of interactive media such as the internet and cellphones, and it is easy to imagine that activities involving searching and sharing information can be done through this media. But we must also consider searching in the real world and sharing activities that might be in the form of obtaining product information from friends and family, or talking to others about someone's reaction after actually using the product, or other communication channels.

\section{Attention Concept}

To attract the attention of the public through websites and social media can be started by holding events and always updating information about the event or about other bank information that can attract the attention of customers or prospective customers. And with Up to Date banking activities and information on social media besides being able to attract the attention of the public, it can also increase recognition and memory of the bank.

\section{Interest Concept}

After getting attention, the next step is get interest. To get public interest by providing complete information and simulations of banking products and services so that the community is interested in funding or financing the bank and can make consideration of prospective customers to tailor products to their needs.

\section{Search Concept}

After get interest, usually people will look for information about products or services or other information about Islamic banking. for that we must provide these facilities with complete website content so that it makes it easier for people to find the information they want.

\section{Action Concept}

In order for the community to take action to make funding or financing at the bank, at this stage what can be done is by providing mobile banking and internet banking services to the bank.

The concept of e-marketing also affects the number of assets. According to Wandanaya (2012), companies can apply a marketing method using cheaper electronic media, namely the internet, so companies can reduce marketing costs and can increase sales volume.

\section{Share Concept}

As we know that consumer behavior (consumer habits) after making an action to buy or making a purchase, the consumer will share or share on social media about the results of using the product, and we can facilitate by providing social media account and website facilities to make it easier interact directly with customers or prospective customers, and also we can always evaluate by looking at suggestions and input given by customers and who wish to make funding or 
Jurnal Ekonomi dan Perbankan Syariah

Vol. 7. No.1, April 2019: 68-78, ISSN (cet): 2355-1755 | ISSN (online): 2579-

6437

| 75

financing at the bank after getting information about products and services provided on the web and social media.

\section{METHODOLOGY}

This study uses descriptive quantitative research because in this study describes the conditions that occur at this time systematically and factually with the aim to explain and resolve the problem under study.

The number of banks used in this study are 13 Islamic Commercial Banks, namely: (1) Bank Muamalat, (2) Bank Syariah Mandiri, (3) Bank BNI Syariah, (4) BRI Syariah Bank, (5) BCA Syariah Bank, (6) Sharia BJB Bank, (7) Bank Bukopin Syariah, (8) Bank Mega Syariah, (9) Bank Panin Dubai Syariah, (10) Bank Victoria Syariah, (11) MayBank Syariah, (12) BTPN Syariah, (13) Bank Aceh.

The tool used is by using a tracking website at www.similarweb.com and analysis of social media and using the AISAS method (Attention, Interest, Search, Action, Share).

This study uses weight calculations. The use of this calculation is intended to find out how big Islamic banks are in the e-marketing concept with the AISAS method (Attention, Interest, Search, Action, Share), which is where:

- Weight 4 = Very Good

- Weight 3 = Good

- Weight 2 = Enough

- Weight 1 = Less Good

This weight assessment is taken based on the results of the analysis obtained. And then the results of the weights will be sorted from the highest to the smallest until the best known Islamic Commercial Bank sequence in the application of e-marketing using the AISAS method (Attention, Interest, Search, Action, Share).

\section{RESULTS AND DISCUSSION}

To find out results of AISAS, we can see from the number of followers on social media and how feedback is given by the community by looking at comments on social media accounts and seeing how interesting the posts are done by looking at the number of likes on social media. And customers or prospective customers can ask privately by asking directly through Direct Message. Inside Fanpage we can find out the comments about the bank and what the rating of the comment is and how many people recommend the bank. And we can also find out how many visitors are on the bank's website by tracking the web at www.similarweb.com. The results obtained are presented in the following 
76 | Silmi Safira, Iqbal Fadli Muhammad, Muhammad Doddy: The Concept of Branding in Islamic Business Ethics Perspetive Analysis of Using Islamic Bank Social Media and Website in The e-Marketing Concept Using Attention, Interest, Search, Action, Share (AISAS) Methods

\begin{tabular}{|c|c|c|c|c|c|c|c|}
\hline & \multicolumn{7}{|c|}{ Table 1: } \\
\hline No & Bank & Attention & Interest & Search & Action & Share & $\begin{array}{c}\text { Total } \\
\text { Weight }\end{array}$ \\
\hline 1 & $\begin{array}{l}\text { Bank Syariah } \\
\text { Mandiri }\end{array}$ & 4 & 4 & 4 & 4 & 4 & 20 \\
\hline 2 & BNI Syariah & 4 & 4 & 4 & 4 & 4 & 20 \\
\hline 3 & Bank Muamalat & 4 & 3 & 4 & 3 & 4 & 18 \\
\hline 4 & BRI Syariah & 4 & 3 & 4 & 3 & 4 & 18 \\
\hline 5 & BJB Syariah & 3 & 3 & 4 & 2 & 3 & 15 \\
\hline 6 & $\begin{array}{l}\text { Bank Bukopin } \\
\text { Syariah }\end{array}$ & 3 & 3 & 3 & 2 & 2 & 13 \\
\hline 7 & $\begin{array}{l}\text { Bank Mega } \\
\text { Syariah }\end{array}$ & 3 & 3 & 3 & 2 & 2 & 13 \\
\hline 8 & $\begin{array}{l}\text { Bank Panin Dubai } \\
\text { Syariah }\end{array}$ & 1 & 3 & 4 & 1 & 2 & 11 \\
\hline 9 & BCA Syariah & 1 & 2 & 4 & 2 & 1 & 10 \\
\hline 10 & BTPN Syariah & 1 & 3 & 3 & 2 & 1 & 10 \\
\hline 11 & Bank Aceh & 2 & 2 & 3 & 1 & 2 & 10 \\
\hline 12 & $\begin{array}{l}\text { Bank Victoria } \\
\text { Syariah }\end{array}$ & 1 & 3 & 3 & 1 & 1 & 9 \\
\hline 13 & MayBank Syariah & 1 & 1 & 2 & 2 & 1 & 7 \\
\hline
\end{tabular}

The top three best banks from the weighting results above that have implemented e-marketing using the AISAS method (Attention, Interest, Search, Action, Share) are respectively Bank Mandiri Syariah, BNI Syariah, Bank Muamalat. While the bottom three are Bank Aceh, Victoria Syariah Bank and MayBank Syariah.

\section{CONCLUSION}

Based on the above analysis regarding the website and social media as a means of e-marketing of Islamic banking, conclusions were obtained in a concise manner. The top three Sharia Commercial Banks that have implemented eMarketing using the AISAS method are: (1) Bank Mandiri Syariah, (2) BNI Syariah, (3) Bank Muamalat.

Most Islamic banks have used social media as a marketing tool, but not all Islamic banks already have a complete website about information about bank products and services.

In addition, the implementation of e-marketing is in line with the development of a number of banking assets.

The managerial implication of this study is that Islamic banking is better at maximizing the approach to the community by utilizing digital media to get 
Jurnal Ekonomi dan Perbankan Syariah

Vol. 7. No.l, April 2019: 68-78, ISSN (cet): 2355-1755 | ISSN (online): 2579-

6437

| 77

the attention of customers or prospective customers. Because in modern times social media is something that is so important for people's lives.

Academically, in this study, the next research is that researchers should be able to obtain data directly from banks that are directly sampled so that they can ascertain how much the role of social media to increase the number of new customers in each bank so that bank data obtained much better and in accordance with the conditions that occur in the field. 
78 | Silmi Safira, Iqbal Fadli Muhammad, Muhammad Doddy: The Concept of Branding in Islamic Business Ethics Perspetive Analysis of Using Islamic Bank Social Media and Website in The e-Marketing Concept Using Attention, Interest, Search, Action, Share (AISAS) Methods

\section{BIBLIOGRAPHY}

Abdullah, R. (2018). 7 in 1 Pemograman Web untuk Pemula. Jakarta: PT Elex Media Komputindo.

Ardha, B. (2014). Ardha: Social Media sebagai media kampanye partai ..., 13(01), 105-120.

Hope, N. (2016). Facebook Marketing: Strategies for Advertising, Business, Making Money and Making Passive Income Free Bonus and Free Gift (3rd ed.). America: CreateSpace Independent Publishing Platform.

Interprise, J. (2013). 100 Aplikasi Andorid Paling Handal. Jakarta: PT Elex Media Komputindo.

Mardiah, N. (2017). Penerapan teknologi dan pengaruhnya terhadap rekrutmen pada lembaga perbankan islam. Lembaga Keuangan Dan Perbankan, 2.

Muhamad. (2015). Manajemen Dana Bank Syariah (2nd ed.). Jakarta: PT Garafindo Persada.

Muljono, R. K. (2018). Digital Marketing Concept. Jakarta: PT Gramedia Pustaka Utama.

Priansa, D. J. (2017). Komunikasi Pemasaran Terpadu. Banudng: CV Pustaka Setia.

Rofiq, A., Arifin, Z., \& Wilopo. (2012). Pengaruh Penerapan Aida ( Attention , Interest , Desire, Action ) Terhadap Keputusan Pembelian.

Sugiyama, K., \& Andree, T. (2011). The Dentsu Way: Secrets of Cross Switch Marketing from the World's Most Innovative Advertising Agency. New York, Untied State: Mc Grow Hill.

Wandanaya, A. B. (2012). Pengaruh Pemasaran Online Terhadap Keputusan Pembelian Produk, 5(2), 174-185.

Wirawan, F. W., \& Hapsari, P. D. (2016). Analisis AISAS Model Terhadap Product Placement Dalam Film Indonesia Studi Kasus: Brand Kuliner di Film Ada Apa Dengan Cinta 2. Jurnal Rekam, 12(2), 69-81. 